\title{
ate Antiquity by Gordon Childe:
Sources and inspirations
}

\author{
Elżbieta Jastrzębowska \\ Polish Academy of Science, Rome, Italy
}

Abstract: In the last chapter of What Happened in History, Childe touched on the problematic of Late Antiquity. His pessimistic view of that period was a variation on the theme of decadence. This theme had existed in the Roman Republic and under the Empire, long before there was any Late Antiquity to be decadent. It then persisted throughout the Middle Ages and found monumental expression in Gibbon's Decline and Fall. Childe, however, took it to excessive lengths in his denunciation of the politics, economy, and culture of the Late Roman Empire. Childe based his arguments largely on the work of Rostovtzeff and Heichelheim. Both these eminent historians were exiles: Rostovtzeff from the Russia of the October Revolution and Heichelheim from National Socialist Germany. It is no belittlement to say that their work was influenced by the insights of their political experiences. Childe, however, did not appreciate this and adopted their thinking somewhat uncritically. He further added parallels between the Roman Period and his own time, which resulted in an unduly dark vision of the last phase of the Roman Empire.

Keywords: decline, Gibbon, Heichelheim, Late Antiquity, Roman Empire, Rostovtzeff, Vere Gordon Childe

Only once in his numerous publications did Vere Gordon Childe touch upon the concerns of Late Antiquity. In What Happened in History, probably his most popular work, he reflected on the topic in a chapter entitled most traditionally and significantly 'The Decline and Fall of the Ancient World'. In summing up his life's scholarly work - in 'Retrospect' - he no less characteristically explained his reasons for writing the text:

I wrote it to convince myself that a Dark Age was not a bottomless cleft in which all traditions of culture were finally engulfed. (I was convinced at the time that European Civilization - Capitalist and Stalinist alike - was irrevocably heading for a Dark Age). So I wrote with more passion and consequently more pretensions to literary style than in my other works. (Childe 1958:73)

These sentences not only explain why Childe concerned himself with a period he knew less about than others, but also show the prism through which he viewed that period, the prism of 1942, which showed the world in a gloomy and sinister light. 
Childe's book treats of the development of human societies from the Palaeolithic period of savagery, through the Neolithic and urban revolutions in Mesopotamia and Egypt, the European Bronze and Iron Ages, to the Mediterranean summit of civilization in Antiquity. His protagonists are not the historical cultures or their participants but their evolution in time, space, and quality as one logical sequence of change seen through the eyes of an open Marxist, who remained at that time under the influence of Soviet archaeology (Lech 1992:17-18). It is a fascinating, albeit simplified, version of history - within the conceptual framework mentioned in 'Retrospect' (Childe 1958:73) - which we read today with great admiration for the author's enormous erudition and unusual talent for synthesis, but not without resistance to the doctrine.

Next to the coherent view of mankind's prehistory presented by Childe, the last chapter, 'The Decline and Fall of the Ancient World', differs clearly from the rest. This distinctness seems to result not just from a lesser knowledge of remains and written sources from Late Antiquity than of prehistoric material, which Childe, in his time, knew like few others. The difference stems primarily from his attitude to that age, full of passion, emotion, and negative assessment of a period when, as he says: 'many refinements, noble and beautiful, were swept away' (Childe 1942:279), and the only consolation could be the thought that 'in those domains that archaeology as well as written history can survey, no trough ever declines to the low level of the preceding one; each crest out-tops its last precursor' (1942:282).

This pessimistic view of Late Antiquity had a long tradition. It reaches back to the Roman Republic, to The Histories of Polybius, in which he described Scipio Africanus musing over the ruins of Carthage in $146 \mathrm{BC}$, recalling the same fate of Troy and foreseeing a similar end for Rome.

Scipio, when he looked upon the city as it was utterly perishing and in the last throes of its complete destruction, is said to have shed tears and wept openly for his enemies. After being wrapped in thought for long, and realizing that all cities, nations, and authorities must, like men, meet their doom; that this happened to Ilium, once a prosperous city, to the empires of Assyria, Media, and Persia, the greatest of their time, and to Macedonia itself, the brilliance of which was so recent, either deliberately or the verses escaping him, he said:

'A day will come when sacred Troy shall perish,

And Priam and his people shall be slain'

And when Polybius speaking with freedom to him, for he was his teacher, asked him what he meant by the words, they say that without any attempt at concealment he named his own country, for which he feared when he reflected on the fate of all things human. Polybius actually heard him and recalls it in his history. (Polybius XXXVIII, 22:1-3. Polybius 1954 vol.VI:439)

In later Roman historiography of the fourth and fifth centuries (Aurelius Victor and Scriptores Historiae Augustae from the second half and end of the fourth century, 
and Zosimos AD 422-519) there are many complaints about the decline of tempora et mores and its pernicious influence on the failing Roman state. In the earlier writings of the Church Fathers (Cyprian AD 200/210-258; Lactantius 250-330; Tertullian 155-220) we come across interpretations of the stormy symptoms of the third century crisis as signs foretelling the end of the world. This was not the only view of the world at the time among writers, both pagan and Christian. From the time of Constantine, with the blessing of the ruling authorities, it was increasingly common for victorious Christianity to be looked upon as the only guarantor of the rebirth and continued prosperity of the Roman Empire. It was the same in later years when in addition to those who saw Byzantium, the Papacy, and the Holy Roman Empire of the German Nation as continuators of the Roman Empire, there were others, like Justinian's chronicler and secretary, Marcellinus Comes, who accepted the year AD 476 as the date marking the fall of Rome. Then, under the leadership of Odoacer, the barbarian conquerors of Italy had forced the last emperor of the West, Romulus Augustus, to abdicate.

In the following centuries the date of AD 476 was, so to speak, formally accepted as a historical event crucial for the fall of the Roman Empire and was passed on (Jordanes in the middle of the sixth century; the Venerable Bede 672-735). Thus, the road was laid out for the Renaissance humanists for whom the darkest of the 'Dark Ages' of medieval times had followed the fateful date of 476 (Flavius Blondus d. 1463; Leonardo Bruni 1369-1444; Petrarca (Petrarch) 1304-1374). The intellectuals of the Enlightenment found a rational explanation for the destruction and fall of Rome in the corruption of good old republican traditions and principles (Montesquieu 1689-1755), as well as in Christianity and the Germanic invasions (Voltaire 1694-1778). All this accumulated in Edward Gibbon's (1737-1794) monumental work The History of the Decline and Fall of the Roman Empire, written in the years 1776-1788. Gibbon's was not, however, a completely gloomy view of the end of the ancient world, since he saw the 'migration of peoples' of that time as a driving force for change and development. This theme was developed even more optimistically in the second half of the eighteenth and in the nineteenth century both by Herder and by Marx. Herder (1744-1803) saw an occasion leading to freedom for enslaved peoples in the fall of Rome. For Marx (1818-1883) the transformation of slavery into feudal serfdom had been a higher degree of development of the forces of production, necessarily leading to the rise of capitalism (see Demandt 1984, 1989:471-474).

Why then did Childe, an evident supporter of Marxism, assess Late Antiquity so harshly in his book What Happened in History? As he put it:

In the scientific arrangement of the vast mass of information thus made available hardly any progress was made. No original creative hypothesis for reducing to order a number of scattered facts was advanced. Not a single major invention was suggested by all the data accumulated. Despite the existence of a large leisured class of cultivated and even learned men, Imperial Rome made no significant contribution to pure science ... In applied science, too, the advances made under the Empire are disappointing in comparison with the resources available. (Childe 1942:267) 
For him Late Antiquity had been 'definitely a step back towards the Oriental economy of the Bronze Age, indeed towards neolithic self-sufficiency' (Childe 1942:274). Moreover:

Economically, as well as scientifically, classical civilization was dead a hundred and fifty years before barbarian invaders from Germany finally disrupted the political unity of the Empire and formally initiated the Dark Age in Europe.

In these hundred and fifty years the later emperors made a heroic if vain attempt to rescue the machinery of civilization by reviving a régime of Oriental centralization, often miscalled State Socialism. A more appropriate term is now available since Nazional-Sozialismus employed almost identical methods for the same purpose of maintaining an antiquated social system. (Childe 1942:276)

With this unjust, partly absurd accusation made in Childe's text one must cease to quote further. It is impossible to agree with these assessments, especially as over half a century has gone by, bringing new analyses and understandings of the period. What is interesting is the reason for such judgements by so great a scholar. They must be contextualized more in the years in which Childe wrote his book than in the epoch that he wrote about.

Childe obtained his information, as he himself admitted, mainly from three monumental social and economic histories of Antiquity: from Michael Rostovtzeff's History of the Ancient World (1927), Social and Economic History of the Roman Empire (1926), and his similar history of the Hellenic world (1941), and from Fritz M. Heichelheim's (1938) Economic History of Antiquity. These great syntheses of ancient economy must be used today with great, though not always equal, discretion, because of the degree to which they were influenced by the times in which the authors lived. Rostovtzeff's books continue to be a mine of useful information partly based on a wide use of archaeological material - he was the first in modern historiography to do so. Heichelheim's work, however, is largely out of date. Both scholars were influenced by their personal life histories which were, to a degree, similar: Rostovtzeff was driven out of Russia by the October Revolution, whereas Heichelheim was forced to emigrate from Germany by Hitler's National Socialism just before the Second World War.

Rostovtzeff was born in 1870 in Zhitomir near Kiev and died in 1952 in New Haven. He was an archaeologist and ancient historian, and was first and foremost a researcher of Greek and Roman economic and social history. His first scholarly article about the administration of the Roman provinces in the time of Cicero appeared already in 1894 during his studies at the University of St Petersburg (Welles 1953:142), where he later became a professor of Latin (1898-1918) and a member of the Russian Academy of Sciences. From 1900 Rostovtzeff was occupied by a major project on the ancient history and the history of the decorative painting of south Russia (Rostovtzeff 1914). In the preface to the last volume of the series, published in England, he wrote a symptomatic statement which showed a new 
approach, characteristic for many ancient historians of that time, but which could just as well have been formulated by Childe:

For me archaeology is not a source of illustrations for written texts, but an independent source of historical information, no less valuable and important, sometimes more important, than the written sources. We must learn and we are gradually learning how to write history with the help of archaeology. (Rostovtzeff 1922: VIII)

A refugee in England after the October Revolution, Rostovtzeff became a professor of Ancient History at Queen's College, Oxford (1918-1920) and then held similar posts in the USA at the University of Wisconsin (1920-1925) and Yale University (1925-1944). On behalf of the latter, he directed the excavations at Dura Europos the Hellenistic, Parthian, and Roman city in Syria. He was 'one of the best known teachers and investigators in the field in the first half of the twentieth century and a strong advocate of the principle of international cooperation in research' (Welles 1953:142). His widely known books mentioned earlier, which were translated into many languages, were also well known to Childe.

Fritz Moritz Heichelheim (b. Gießen 1901, d. Toronto 1968) was a traditional German ancient historian, self-defined as an Altertumswissenschaftler, who specialized in ancient economic history. Heichelheim was a pupil of the ancient historian Richard Laqueur at the University of Gießen, where he was awarded his doctorate in 1925 (Die auswärtige Bevölkerung im Ptolemäerreich) and his habilitation in 1929 (Wirtschaftliche Schwankungen der Zeit von Alexander bis Augustus). After lecturing there for nearly four years, he, like his colleague at Gießen, Margarete Bieber, was dismissed in 1933 in accordance with the National Socialists' 'cleansing' of the universities. Like many German scholars, in 1933 he was forced to emigrate abroad, in his case to Great Britain and, in 1951, to Canada where, from 1962, he was a professor of Greek and Roman History at the University of Toronto. During his work as a lecturer of Ancient History and Archaeology at the University of Nottingham he took part in the excavations 'in one of the neighbouring Roman sites' (Gundel 1969:222). His specializations were Greek and Roman economic history, Greek and Roman numismatics, papyrology, Greek and Roman epigraphy, and Gallo-Roman religion. His main work, well known to Childe, was Wirtschaftsgeschichte des Altertums vom Paläolithikum bis zur Völkerwanderung der Germanen, Slaven und Araben (Heichelheim 1938). He wrote it during his stay in England (Cambridge and London). Earlier, in Germany, he contributed several articles to the Realenzyklopädie of Pauly and Wissowa (1894-1972), and in England also contributed to the Oxford Classical Dictionary (Oxford 1949).

The personal fortunes of both scholars undoubtedly impacted on their opinions as researchers. Rostovtzeff, a 'white' Russian, thoroughly hated the 'red' Bolsheviks, and at international congresses was demonstrative in his refusal to come in contact with anyone from the Soviet Union. However, he was himself not completely free from the Marxist method of analysing material and saw the reasons for the crisis of the third century in the class struggle, in the antagonism between the primitive 
soldiery coming from the impoverished peasantry and the wealthy bourgeoisie of the cities. He wrote:

I feel no doubt, therefore, that the crisis of the third century was not political but definitely social in character. The city bourgeoisie had gradually replaced the aristocracy of Roman citizens, the senatorial and the equestrian class. It was now attacked in turn by the masses of the peasants. In both cases the process was carried out by the army under the leadership of the emperors. The first act ended with the short but bloody revolution of A.D. 69-70, but it did not affect the foundations of the prosperity of the Empire, since the change was not a radical one. The second act, which had a much wider bearing, started the prolonged and calamitous crises of the third century. Did this crisis end in a complete victory of the peasants over the city bourgeoisie and in the creation of a brand-new state? ... There is no shadow of doubt that in the end there were no victors in the terrible class war of this century. If the bourgeoisie suffered heavily, the peasants gained nothing ... A movement which was started by envy and hatred, and carried on by murder and destruction, ended in such depression of spirit that any stable conditions seemed to the people preferable to unending anarchy. (Rostovtzeff 1926:448)

and

The last signs of civil freedom disappeared: it was the reign of spoliation and arbitrary violence, and even the best emperors were powerless to struggle against it. (1926:318)

This particular dark vision of the third century $\mathrm{AD}$ in antiquity was also criticized by other scholars. Rostovtzeff was accused of transferring his own experiences from the twentieth century and the period of the Soviet revolution to the third century (Demandt 1989:37-38). In the subsequent editions and translations of his Social and Economic History of the Roman Empire, however, he refuted these accusations stating that there was no connection between the situation in Late Antiquity and his own time. However, he himself exposed such analogies:

A striking private letter from Oxyrhynchus may also be quoted. Charmus writes to his brother Sopatrus: 'The prefect has sent an amnesty here, and there is no longer any fear at all; so, if you will, come boldly; for we are no longer able to stay in doors. For Annoë is much worn out with her journey, and we await your presence, that we may not withdraw without reason; for she considers herself to be keeping house here alone'. The enigmatic sentences, comprehensible to the addressee, remind me of many letters which I receive from Soviet Russia. The system of terrorism gives rise to the same phenomena everywhere and at all times. (Rostovtzeff 1926:436)

On his part, Fritz Heichelheim had no scruples in ascribing to the ancient emperors the methods of the modern totalitarian power so hateful to him. For instance, 
referring to Diocletian's price edict of AD 301 he wrote: 'Ignoring the price edict brought the death penalty to merchant and customer, employer and employee, a severe measure which finds many analogies in Soviet Russia and the recent regime in Germany' (Heichelheim 1970:vol.III, 293).

The fate of Rostovtzeff and Heichelheim was not exceptional in the first half of the twentieth century in Europe. There were many other scholars of German, Hungarian, and Russian origin who researched Late Antique sources and remains in similar personal circumstances. Among them, there was Ernst Kantorowicz (b. Prussian Poznań 1895, d. Princeton 1963), an art historian and professor at the University of Frankfurt who, as a Jew, was forced to flee to England and then to the USA. A second example is that of Andreas Alföldi (b. Budapest 1895, d. Princeton 1981), an ancient historian and professor at the University of Budapest, who as a refugee in 1947, arrived in the Institute for Advanced Studies in Princeton. Finally, André Grabar (b. Kiev 1896 d. Paris 1990) a historian of Roman and Byzantine Art and archaeologist who fled through Odessa to the West after the October revolution and from 1922 lived in France. There he became a professor at the École Pratique des Hautes Études in 1937, and also took part in excavations of Byzantine sites. Their attitude towards the past, a uniting factor in the life and work of these three great scholars, was, according to Matthews (1993:19), in a way different to that of Rostovtzeff and of Heichelheim; it was 'a nostalgia for lost empire: Russian, Prussian and Austro-Hungarian emperors', which, incidentally, would be of no interest to Childe the Marxist.

Childe was not a dogmatic Marxist and his visits to Soviet Russia, as well as his close acquaintance with the work of the archaeologists in that country both in the area of ideological theory and practical excavation work, sharpened his critical faculties towards sundry ideological simplifications of history. As Trigger (1989:257) rightly noted: 'Writing under the shadow of expanding Nazi Power and World War II, He also rejected the naive faith in the inevitability of progress that characterized many vulgarized versions of Marxism as well as the unilinear cultural evolutionism of the nineteenth century'.

In the second quarter of the twentieth century, in a time of bloody revolution and world war, researchers of European history found it extremely difficult to free themselves from comparisons crossing over the centuries. For some of those who experienced it, the nightmare of revolution and two world wars was perceived as the fall of European civilization. This perception was informed by the idea of a fall formed by Gibbon and others in the eighteenth century, who had linked it to Late Antiquity, a perception that had become strongly encoded in the minds of educated Europeans. In this situation Childe's pessimistic vision of Late Antiquity and his opinions on that age become comprehensible. The last chapter of What Happened in History should be read critically, taking into account that the author was burdened by the brutality of the times in which he wrote. The generalizing conclusions to be found there should not be taken as other than an intellectual and emotional challenge, with regard both to the fall of the ancient world and Christianity, to which Childe had a critical, in fact an ahistorical attitude. Research into Late Antiquity has distinguished and set apart this time of contrast as a separate great chapter in the history of the Mediterranean world. Evaluation, for historians, will always depend on their convictions about the evolution of societies, including the society of which they are a part. 


\section{REFERENCES}

CHILDE, V.G., 1942. What Happened in History. Harmondsworth: Penguin.

CHILDE, V.G., 1958. Retrospect. Antiquity 32:69-74.

DemandT, A., 1984. Der Fall Roms. Die Auflösung des römischen Reiches im Urteil der Nachwelt. München: C.H. Beck.

DemandT, A., 1989. Die Spätantike. Römische Geschichte von Diocletian bis Justinian 284-565 n. Chr. München: C.H. Beck.

GiBBon, E., 1776-1788. The History of the Decline and Fall of the Roman Empire. London: F. Warne.

GUNDEL, H.G., 1969. Fritz M. Heilchelheim. Gnomon 41:221-224.

HeICHELHEIM, F.M., 1938. Wirtschaftsgeschichte des Altertums vom Paläolithikum bis zur Völkerwanderung der Germanen, Slaven und Araben. Leiden: A.W. Sijthoff.

HeichelheIm, F.M., 1970. An Ancient Economic History from the Palaeolithic Age to the migrations of the Germanic, Slavic, and Arabic nations. Leiden: A.W. Sijthoff.

LECH, J., 1992. V. Gordon Childe a archeologia środkowej i wschodniej Europy. W stulecie urodzin [V. Gordon Childe and central and eastern Europe archaeology. In the centenary of his birth]. Acta Archaeologica Carpathica 31:5-33.

Matthews, T.F., 1993. The Clash of Gods. A Reinterpretation of Early Christian Art. Princeton, NJ: Princeton University Press.

OxFORD, 1949. Oxford Classical Dictionary. Oxford: Clarendon Press.

PAuly, A.F. and G. WissowA, 1894-1972. Paulys Real-Encyclopädie der classischen Altertumswissenschaft. Stuttgart: J.B. Metzler.

PolyBIUS, 1954. The Histories (translated by W.R. Paton). London: The Loeb Classical Library.

RostovtzeFF, M., 1914. Antičnaja dekorativnaja živopis' na iug' Rossij. Sankt Petersburg: Izdanija Imperatorskoj Archeologičeskoj Kommissij.

RostovtzeFF, M., 1922. Iranians and Greeks in South Russia. Oxford: Clarendon Press.

Rostovtzeff, M., 1926. The Social and Economic History of the Roman Empire. Oxford: Clarendon Press.

RostovtzeFf, M., 1927. A History of the Ancient World. Oxford: Clarendon Press.

RostovtzefF, M., 1941. The Social and Economic History of the Hellenistic World. Oxford: Clarendon Press.

Trigger, B.G., 1989. A History of Archaeological Thought. Cambridge: Cambridge University Press.

WELlES, C.B., 1953. M.I. Rostovtzeff. Gnomon 25:142-144.

\section{BIOGRAPHICAL NOTE}

The author was born at Polanica-Zdrój in Poland and studied Classical Archaeology at Warsaw University; graduating with an MA (1969) on Terra Sigillata Pottery in the National Museum in Warsaw. She has participated in excavations in England at High Lodge, Suffolk, and Margidunum, Nottinghamshire; in Poland at Saspów, Olszanica, and Iwanowice, near Cracow; and in Italy at Marzabotto. Her specialization in Late Antique and Early Christian Archaeology at the Pontifical Institute of Christian Archaeology at Rome and at the University of Freiburg (Germany) led to a PhD on Untersuchungen zum christlichen Totenmahl aufgrund der Monumente des 3. und 4. Jhs. unter der Basilika des Hl. Sebastian in Rom, and her Veniam Legendi in 1992 was on Bild und Word: das Marienleben und die Kindheit Jesu in der christlichen Kunst vom 4. bis 8. Jh. und 
ihre apokryphen Quellen In 1972-1974 she was Assistant Professor in the Department of Classical Archaeology at the Catholic University of Lublin; in 1990-2004 Professor at the Institute of Archaeology, University of Warsaw; and from 2005 to date: Director of the Polish Academy of Science at Rome.

Address: Polish Academy of Science, Vicolo Doria 2, 00178 Roma, Italy [email: e.jastrzebowska@accademiapolacca.it]

\section{ABstracts}

L'Antiquité tardive par Gordon Childe : sources et inspirations Elżbieta Jastrzębowska

Dans le dernier chapitre de What happened in History, Childe abordait la problématique de l'Antiquité tardive. Sa vue pessimiste de cette période était une variation sur le thème de la décadence. Ce thème existait déjà pendant la République Romaine et l'Empire, donc longtemps avant qu'il n'y ait eu une Antiquité tardive qui put être décadente. Il persistait ensuite tout au long du Moyen Âge et trouva son apogée dans l'œuvre de Gibbons, 'Decline and Fall'. Childe cependant exagérait quelque peu dans sa dénonciation de la politique, économie et culture du dernier empire romain. Ses arguments se basaient largement sur les œuvres de Rostovtzeff et de Heichelheim. Ces deux éminents historiens étaient des exilés : Rostovtzeff de la Révolution d'Octobre en Russie, et Heichelheim de l'Allemagne national-socialiste. Ce n'est pas une dévalorisation de dire que leur travail était influencé par leurs expériences politiques. Childe cependant ne tenait pas compte de ces faits et adoptait leur manière de penser sans trop de réserves. De plus, il ajoutait des parallèles entre l'époque romaine et son temps, ce qui menait à une vision excessivement sombre de la dernière phase de l'Empire Romain.

Mots clés: déclin, Gibbon, Heichelheim, Antiquité tardive, Empire Romain, Rostovtzeff, Vere Gordon Childe

(translation by Isabelle Kayser-Gerges)

\section{Spätantike von Gordon Childe: Quellen und Inspirationen \\ Elżbieta Jastrzębowska}

Im letzten Kapitel von What Happened in History riss Childe die Problematik der Spätantike an. Seine pessimistische Sicht dieser Periode war eine Variation des Themas der Dekadenz. Dieses Thema hat in der Römischen Republik und während des Römischen Imperiums existiert - lange bevor eine Spätantike bestand, die dekadent sein konnte. Dann setzte es sich während des Mittelalters fort und fand einen monumentalen Ausdruck in Gibbons Decline and Fall. Childe dagegen benutzte es ausführlich in seiner Anklage von Politik, Ökonomie und Kultur des Spätrömischen Reiches. Childe gründete seine Argumente weitgehend auf den Arbeiten von M. I. Rostovzev und F. Heichelheim. Beide dieser berühmten Historiker waren Exilanten: Rostovzev floh vor der russischen Oktoberrevolution, Heichelheim vor dem nationalsozialistischen Deutschland. Es ist keine Verharmlosung zu sagen, dass ihr Werk durch die Erkenntnisse ihrer eigenen politischen Erfahrungen beeinflusst war. Childe dagegen berücksichtigte dies nicht und übernahm ihre Gedanken relativ unkritisch. Weiterhin fügte er Parallelen zwischen der Römischen Epoche und seiner eigenen Zeit hinzu, die zu einer übermäßig düsteren Vision der letzten Phase des Römischen Reiches führten.

Schlüsselbegriffe: Verfall, Spätantike, Römisches Reich, Edward Gibbon, Fritz Heich elheim, Michail I. Rostovzev, Vere Gordon Childe 